We have then the apparent compressibility

$\begin{array}{lllll}\text { of water in glass at } 2^{\circ} 5^{\circ} \mathrm{C} & \ldots & \ldots & \ldots & 0 \\ 0 & 04868\end{array}$

$\begin{array}{llllll}\text { Add compressibility of glass } & \ldots & \ldots & \ldots & 0.00292\end{array}$

True compressibility of water at $2 \cdot 5^{\circ} \dddot{\mathrm{C}}$. $\quad \cdots$

And the apparent compressibility of water

$\begin{array}{llllllll}\text { at } 12.5^{\circ} \mathrm{C} \text {. is } \ldots & \ldots & \ldots & \ldots & \ldots & \ldots & \ldots & 0 \\ 0\end{array}$

$\begin{array}{lllllll}\text { Add compressibility of glass } & \ldots & \ldots & \ldots & 0 \\ & \ldots & \ldots & \ldots & 04292\end{array}$

True compressibility of water at $125^{\circ}{ }^{\circ} \mathrm{C}$. ...

Grassi gives the following values for the true compressibs of water at various temperatures :-

$$
\begin{aligned}
& \text { At } 1.5{ }^{\circ} \text { C. ... }
\end{aligned}
$$

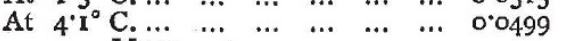

$$
\begin{aligned}
& \text { Mean } \cdots, \cdots, \cdots, \ldots \\
& \text { At } 10.8^{\circ} \text { C. ... }
\end{aligned}
$$

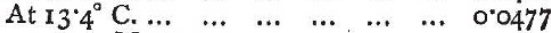

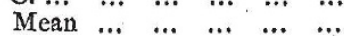

My results agree very closely with these.

Before concluding I would call attention to a very curious phenomenon which I have never seen noticed, namely, the peculiar noise which accompanies the relief of pressure in a mixture of ice and water.

In comparing the Piezometer $\mathrm{K}$ No, 4 , in melting ice with the manometer at $12.5^{\circ} \mathrm{C}$., I proceeded gradually from lower to higher pressures. When the pressure which was relieved was IOO or I 20 atmospheres, I thought I noticed a slight noise. On raising the pressure higher the noise became more and more distinct, until when the pressure relieved was over 200 atmospheres, it was distinctly audible at a distance of 5 feet or 6 feet. It resembles the noise produced by bending a piece of tin backwards and forwards, and is markedly intensified by accelerating the relief, just as the noise made by blowing off steam is intensified by enlarging the outlet. When the relief valve is opened very carefully it whispers gently but very distinctly, till the pressure is all down. If opened comparatively briskly, but still with great care, the noise is comparatively loud but more rapidly used up. I forbear making any reflections until I have been able to study this phenomenon more closely.

Pieces of clear ice which had been subjected to high pressure in the receiver were finely laminated in parallel planes. In each plane there was a central patch surrounded near the sides of the block by a ring of spherules.

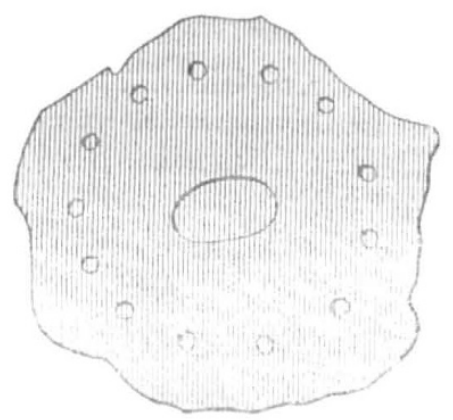

The annexed figure gives an idea of the arrangement in a plane of lamination; the size of the spherules is greatly exaggerated.

The lamination of ice by pressure in one direction is well known. I am not aware that its production by pressure in all directions has been noticed. I hope to pursue my observations on this subject.

J, Y. BUCHANAN

\section{THE CONGRESS OF BOHEMIAN PHYSICIANS AND NATURALISTS}

THE first Congress of Bohemian Naturalists and Physicians met at Prague on May 14 last. More than 400 members met under the presidency of M. Krejcí, M, Eiselt, M. Koristka, and M. Studnicka. The first general meeting was opened by M. Krejcí, Professor of Geology, who delivered an inaugural address "On the share of the Bohemian Nation in the Development of Natural Science." He showed that not only Bohemian workers in science were in the field up to the seventeenth century, but that when the Bohemian nation, after two centuries of political and national slavery, awoke to life again, it very soon took its part in the progress of natural science. The names of Purkyne, Rokytanský, Skoda, Bohdálek, Pitha, Blazina, Safarík, Celakovský, Fric, Krejcí, Helmhacker, and of many others, are known even beyond the boundaries of Bohemia. Many obstacles were placed in the way of these promoters of science; they were not assisted by Government, and even the ancient university of Prague was, and indeed is, almost exclusively German. But in spite of all difficulties scientific progress went on steadily, and at present tl.e number of workers in scienceris very fair. Knowing the cosmopolitan character of science, the Bohemian nation values equally the progress made in England, France, Germany, Italy, and Russia ; it wishes only that its own share-if proportionately small-may be recognised by others. The great languages of the world are like the sea, which carries the ships and steamers of all nations; but the languages and literature, of small nationalities-of the Danes, Swedes, Dutch, and Bohemians-resemble so many rivers irrigating and fertilising the continents by which the sea is surrounded.

On May $\mathrm{I}_{5}$ and $\mathrm{r} 7$ sectional meetings took place. On the I6th the members visited the village Chuchsl, where Prof. Krejcí explained to them the very interesting distortions of the silurian strata on the left bank of the river Vltava (Moldau). In the evening of the same day the members assembled at a banquet, where especially the healths proposed by Prof. Safarik were heartily responded to. IHe spoke first of the progress of science in Bohemia and its relation to scientific investigation in England and France; he then proposed the health of the distinguished Russian naturalists, referring chiefly to Mendeleeff, Butleroff, Menshutkin, Chebysheff, Shecheneff, Mechnikoff, and Kowa. lewski ; finally he drank to the Nestor of palacontological research, to Joaquin Barrande, who at Pragte has carried out the chief part of his scientific work.

In the first section (medicine) papers were read on purely professional subjects.

The second section was devoted to mathematics. Besides several mathematical papers Prof. Augustin spoke on cyclones and anticyclones; $M$. Doubrava read a paper on electricity; M. Domalip explained the action of a magnet on a current of electricity traversing a rarified medium; Prof. Charles Zengef gave an account of his method of constructing achromatic lenses by means of a combination of crown-glass and certain liquids. Excellent microscopic photographs made by the aid of these lenses were shown. For astronomical purposes lenses with an opening of 2 inches and a focal distance of only 9 inches have been constructed according to this method with complete success.

In the third section (Natural Science) the following papers were read:-Prof. Borický, on the structure of the Bohemian porphyries. He showed that they frequently contain the mineral "cordierite," which hitherto had not been found in Bohemia. According to Prof. Borický a great part of the Bohemian porphyries must be classed as siliceous porphyrites. Prof. Fric demonstrated a new genus of the ganoids found at Kounová, near Rakovník. This fish resembles the genus Palæoniscus, but its scales are very different. He gave to the new genus the name of Trissolepis kounoviensis.

M. Bayer gave a report on the characters of the skulls of some batrachia. Comparing the skull of the genus Pelobates with that of other genera, he found that the skull of Pelabates differs essentially from all others, and that this genus does not form the connecting link between the Ranidæ and the Bufonidx. M. Hellich read a report on the genital apparatus of the genus Cypris. He supplemented the data given by Zenker, and corroborated in \& certain sense the new observations of Weissmann. A series of plates belonging to a new work on Bohemian cretaceous Echinodermata was shown by Dr. Ottomar Novák, and their peculiarities were explained. M. Ladislav Duda gave a preliminary account of the anatomy of the Bohemian hemiptera, especially of the section Scutata. He has discovered on the fore feet of these insects a comb-like apparatus, by means of which the insect cleans its tentacles. In Bohemia as yet 40 I species of hemiptera have been found. Prof. Borický showed to the members many interesting novelties in mineralogy, as, e.g., the Rösslerit, a mineral of which as yet only three specimens are known. Dr. Vejdovsky exhibited the second part of his work on the comparative morphology of the annelids, containing a new system of the Oligochrta and their anatomical details, together with their affinities to the Turbellaria and vertebrata. Dr. Vejdovský pro. poses the following arrangement of the new families of the Oligochæta :-(x) Amedullata (Aeolosoma), (2) Chætogastrida, (3) 
Discodrilida (Branchiobdella), (4) Naidea, (5) Echytraeida, (6) Tubificida, (7) Lumbriculida, (8) Phreorzetida, (9) Criodrilida, (10) Lumbricida. M. V. Fric showed to the members a specimen of the body of a chimpanzee, four years old, which was prepared by the injection of Wickersheim's conserving fluid. $\mathrm{He}$ explained all methods hitherto known and used to preserve the bodies of animals, and he declared the method of Wickersheim to be the best of them.

In chemistry some interesting papers were read and an animated discussion took place on educational and scientific questions.

On the 17 th the second general meeting took place, Prof. Albert, of the Innsbruck University, delivering an address "On Theory and Practice in University Education."

During the session of the Congress a journal was published containing the abstracts of the papers read before the Congress. The addresses of M. Krejci and Dr. Albert, however, were printed in extenso, and of the former afterwards also a German translation appeared in print.

\section{SCIENTIFIC SERIALS}

Archives des Sciences Physiques et Naturelles, July r 5, No. 7.- Note on the equilibrium of solids of great dimensions, by M. Cellerier. - Geological description of the Canton of Geneva, hy M. Favre.-Phytography, \&c. (M. de Candolle), by M. Micheli.-A differential thermometer for demonstration, by M. Dufour.-On the casting of the beak of birds of the Mormonides family, by M. Bureau.

Reale 1stituto Lombardo di Scienze e Lettere Rendiconti, vol. xiii, Fasc. xiii. June 17.-On some trigonometric series, by Prof. Beltrami.-Morphological studies on the human body, by Prof. De Giovanni.-On the part taken by the pneumogastric in death by hanging, by Prof. Tamassia.-Iconography of the Laplanders, by Prof. Mantegazza.-On reflex arthropathia of urethritis, by Prof. Scarenzio.-On a geological congress held at Rome, by Prof. Taramelli

Fasc, xiv., July $\mathbf{x}$-O Ossiferous breccia and neolithic station in Corsica, by Dr. Major.-On the present geographical distribution of Nyctinomus cestonii, Gavi., by Dr. Beltoni.-On a shower of falling stars observed at Milan on June 22, 1880, by $\mathrm{S}$. Fornioni and Prof. Schiaparelli,-On univocal plane transformations and particularly on involutory, by Prof. Bertini. Notes on the fishes, and in particular on the male eels, observed at the Berlin Exhibition, by Prof. Pavesi.

\section{SOCIETIES AND ACADEMIES \\ PARIS}

Academy of Sciences, August 9.-M. Wurtz in the chair.The following papers were read:- Summary report of a zoological exploration in the Bay of Biscay in the Government ship Travailleur, by M. A. Milne-Edwards. - Experiments tending to prove that fowls vaccinated for cholera are refractory for charbon, by M. Pasteur. - Results of observations of solar spots and facula during the first two quarters of 1880 , by P. Tacchini, The numbers indicate rapid increase of solar activity. The days without spots form five groups separated by a mean interval of twenty-nine days, showing that in one hemisphere (which is that visible in the end of last December) the spots were formed with difficulty.-On a class of linear differential equations of the second order, by M. Brioschi.-Experiments on the discharge in rarefied gases, by $\mathrm{M}$. Righi. Inter alia, the glass seems to become luminous at the point where it acts as positive electrode. During discharge the negative electrode is probably much more heated than the positive. The cause of mechanical action of the negative electrode is the same as in the radiometer.-On some properties of flames, by M. Meyreneuf. The gas which feeds a flame is subject to two opposing influences, one creating a draught outwards, the other (expansion through combus. tion) tending to drive the gas back. By diminishing the rate of outflow without modifying the combustion, one may regu. late these movements so as to get vibrations of the nature of sound. Better sonorous effects are had by making a flame impinge on a round rod or on another flame. - Indices of refraction of aqueous solutions of acetic acid and of hyposulphite of soda, by M. Damien. - On an improvement of the Bunsen battery by M. Azapis, by M. Ducretet. For acidulated water is substituted a 15 per cent. solution of cyanide of potassium, caustic potash, marine salt, or ordinary sal ammoniac. The zincs need not be amalgamated. They are less consumed than in the Bunsen; the intensity of the current is no less, and its constancy is remarkable.-On the spectra of ytterbium and erbium, by M. Thalén. -On thulium, by M. Clève. - Researches on the heats of "combustion of some substances of the fat-series, by M. Louguinine. - Secondary reaction between sulphuretted hydrogen and hypo. sulphite of soda, by M. Bel'amy.-On the acid obtained by M. Boutroux in the fermentation of glucose, by M. Maumené.-On a new process for producing malleable nickel of different degrees of hardness, by M. Garnier. This consists in incorporating phosphorus with the nickel (to take up oxygen) ; e.g., adding to the bath of nickel a phosphide of nickel containing about 6 per cent. phosphorus. Very thin sheets of the material can be produced.-On propylnervine, by Mr. Morley.-Influence of light on transpiration of plants, by M. Comes. Plants transpire more in light than in darkness, and more the intenser the light. The more intense the colour of the organ, the greater the transpiration. The luminous rays absorbed alone favour the transpiration.-On the source of muscular work and on supposed respiratory combustions, by M. Sanson. The liberation of energy is due greatly, if not wholly, to phenomena of dissociation similar to those in fermentations; in presence of anatomical elements (blood-corpuscles specially) the immediate principles of the plasma are dissociated, give carbonic acid and doubtless other compounds which borrow oxygen from the hæmoglobin for their formation, and yield their energy to the muscular elements, which then manifest it by doing work in contracting, or to the blood for maintenance of animal heat.-On the use of nitrite of ethyl for rendering contaminated places healthy, by M. Peyrusson. It acts like ozone, but more powerfully.-Complement of the biological evolution of pucerons of galls of poplar (Pemphigus bursarius, Lin.), by M. Lichtenstein.-On the affinities of the genus Polygordius with annelides of the family of Opheliide, by M. Giard.-Discovery of new mammalia in the phosphate of lime deposits of Quercy (Upper Eocene) by M. Filhol.-On the structure and functions of the embryonal suspensor in some leguminous plants, by M. Guignard.-On deforming pilosism in some plants, by $M$. Heckel.-On a new instrument for pointing guns, by M. Arnoux.

\section{CONTENTS}

PAGH

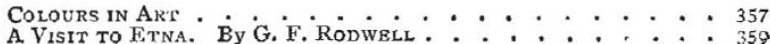
A Visit to ETNA.

Petersen's "Methods and Theories for the Solution of Problems of Geometrical Construction, applied to 4 ro Problems," and "Text-book of Elementary Plane Geometry". . . . . . . 360 Tilden's "Practical Chemistry" . . . . . . . . 360 LETTBRS TO THE EDITOR:-

A Rotatory Polarisation Spectroscope of Great Dispersion.-Pruf

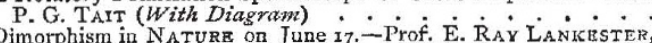
Dimorphism in NatURe on June 17.-Prof. E. RaY Lankrster, Magnetic and Earth-Current Disturbance-Wirira Eris : Aurora Borealis and Magnetic Storms.-Rev. S. J. PERRY, F.R.S. J. A. B. Ollver; F. T. MOTT; B. W, S.

Height of the Aurora-John 1. PLUMMER

Fire Eall. - Rev. S. J. PerRy, F.R.S.

Atmospheric Phenomenon.-B. W. $S$.

Intellect in Brutes. - Dr. HRNRY MACCorma

Radiation-A Query. - F. G. S.

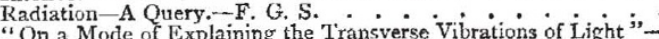
On a Mode of Explaining the Transverse Vibrations of Light The Expression Radiant Matter.

Earthquake in Smyrna.-HYDE C

New Biological Term. -D. SHARP Giaved Taste in Animals:-F. R. GRENood

Depraved Taste in Animals:Finng a Tallow Candle through a Deal Board, C. J. Woodwar TiIUNDERSTRM. II. By Puyan hros without appasatus, iri. (With illustrationis)

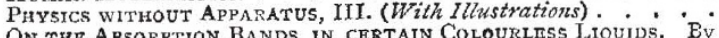

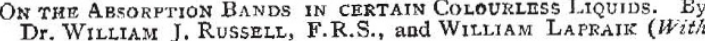
Dr. WILLIAM J. RUSSELL, F.R.S., and WILliAM LAPRAIK (Wit/2
Diagram). . . . . . . . . . . . . . . . .

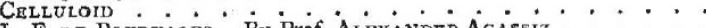
L. F. de Povrtales. By Prof. Alemander Agassiz . * * * . 377

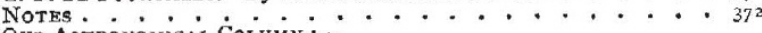
OUR Astronomical Column :-

The August Meteors . . . . .

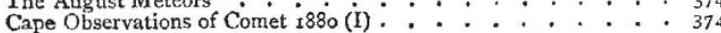

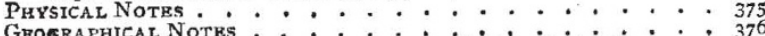

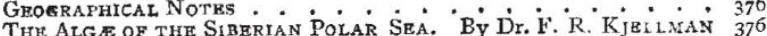
ON THE COMPRESSIBILITY OF GLASS. BY J. Y. BUCHANAN * • • 377 Thr Congress of Bohrmian Physicians and Naturalists . . . 379

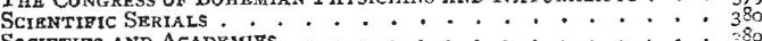

